\title{
Ozonation of Azo Dye Acid Black 1 under the Suppression Effect by Chloride Ion
}

\author{
Alexandre Paprocki, Heldiane S. dos Santos, Marta E. Hammerschitt, \\ Marçal Pires and Carla M. N. Azevedo*
}

Faculdade de Química, Pontifícia Universidade Católica do Rio Grande do Sul, Av. Ipiranga, 6681, 90619-900 Porto Alegre-RS, Brazil

\begin{abstract}
O objetivo deste estudo é determinar a cinética degradação do corante Acid Black 1 por ação oxidante do ozônio e avaliar a influência da contaminação de íons cloreto na degradação deste corante. Foram observadas cinéticas de pseudo-primeira ordem, tanto para a degradação das estruturas cromóforas $(620 \mathrm{~nm})$, quanto das aromáticas $(321 \mathrm{~nm})$. A completa remoção da coloração foi verificada em $25 \mathrm{~min}$ ([corante $]_{0}=1,8 \times 10^{-5} \mathrm{~mol} \mathrm{~L}^{-1}$ ), enquanto que as estruturas aromáticas foram degradadas com menor velocidade. A presença de íon cloreto, principal impureza do reagente sólido, influencia significantemente a velocidade de ozonização ( $-42 \%)$, mesmo em baixa concentração $\left(5,6 \times 10^{-4} \mathrm{~mol} \mathrm{~L}^{-1}\right)$. O mecanismo mais provável para o efeito supressor do íon cloreto envolve a direta reação entre $\mathrm{O}_{3} \mathrm{e} \mathrm{Cl}^{-}$gerando $\mathrm{HOCl}$, dentre outros subprodutos. Apesar deste aspecto, a ozonização pode ser um processo de degradação competitivo para este corante.
\end{abstract}

The aim of this study is to determine the kinetics of the Acid Black 1 dye by oxidizing action of ozone and to evaluate the influence of chloride ion contamination on the dye degradation. Pseudofirst order kinetics was observed for both decolorization $(620 \mathrm{~nm})$ and aromatic structure $(321 \mathrm{~nm})$ degradations. A complete color removal was verified in $25 \mathrm{~min}\left([\text { dye }]_{0}=1.8 \times 10^{-5} \mathrm{~mol} \mathrm{~L}^{-1}\right)$, while aromatic structures degraded at slower rates. The presence of chloride ion, the principal impurity of the solid dye reagents, influences significantly the ozonation rate $(-42 \%)$, even at low chloride concentration $\left(5.6 \times 10^{-4} \mathrm{~mol} \mathrm{~L}^{-1}\right)$. The most probable mechanism for the chloride suppression effect involves a direct reaction between $\mathrm{O}_{3}$ and $\mathrm{Cl}^{-}$generating $\mathrm{HOCl}$, among other by-products. In despite of that, ozonation could be a competitive degradation process for this dye.

Keywords: azo dye, ozonation, salt additives, chloride ion, suppression effect

\section{Introduction}

The Acid Black 1 (C.I. 20470) is an important azo dye widely used in the textile industry. This compound is used not only to dye or to print on synthetic and natural fibers, but also as intermediate in the synthesis of other azo dyes. Another application of the Acid Black 1 is as indicator to assist in the protein separation for chromatography and electrophoresis analyses. ${ }^{1}$

Textile effluents, when not correctly treated, can cause high impact to the environment. Azo dyes are considered as harmful compounds due to their mutagenic and carcinogenic characteristics. The toxicity of theses dyes is often related to the amines employed or formed in their syntheses. ${ }^{2}$

Dye wastewaters can be treated by conventional processes, such as activated carbon absorption or

*e-mail: cazevedo@pucrs.br coagulation, or by alternative technologies including electrochemical treatment, ${ }^{3,4}$ absorption using new materials and advanced oxidative processes (AOPs). ${ }^{5}$ Despite the fact that ozonation in acid medium is not an AOP, $\mathrm{O}_{3}$ proved to yield excellent results on dye effluents treatment. ${ }^{6-9}$ Some studies have been reported about destruction of Acid Black 1 by ozonation. ${ }^{10-13}$ However, none of these studies concerned the by-products formation during ozone attack.

The possible interferences on ozonation efficiency by the presence of additives have been reported for the treatment of the dyes, ${ }^{9,11,14,15}$ as well as for other class of compounds. ${ }^{16,17}$ However, the available information concerning the role of these dye additives on the kinetics and by-product formation is scarce. ${ }^{16}$ The inorganic salts are the most common additives used, as exhausting and retarding agents, during textiles dyeing processes and its quantity varies from 5 to $60 \mathrm{~g} \mathrm{~L}{ }^{-1} .{ }^{18} \mathrm{Gahr}$ et $\mathrm{al} .{ }^{19}$ mentioned the effect of salt during ozone decoloration of reactive dye 
effluent and reported that, at higher levels, the presence of salt lowers the decomposition of reactive dyes.

Muthukumar et al. ${ }^{11}$ observed that the ozonation kinetics of the Acid Black 1 is affected by the presence of some sodium salts (carbonate, chloride and sulfate). These authors explained the influence of added salts by side-reaction with $\mathrm{O}_{3}$, which becomes less available for dye degradation. However, with respect to chloride ion, Gunten ${ }^{20}$ stated that inorganic chlorine-derived by-products are only formed during ozonation if $\mathrm{Cl}^{-}$aqueous solution is pretreated with chlorine or chlorine dioxide.

The influence of the impurities, commonly encountered in commercial dyes, is less studied. According to Lyon, ${ }^{21}$ these impurities present in dyes are: $(i)$ diluents such as inorganic salts, starch and dispersing agents; (ii) by-products formed during manufacture and (iii) dyes of different constitution and color that are added for shading. Zhang and co-workers ${ }^{14}$ investigated the effects of impurities on the ozonation degradation of the azo dye C.I. Reactive Red 120. These authors compared the results obtained for unpurified (75\%) and purified (90\%) dyes, and concluded that the presence of impurities affects mostly the biodegradability of the dye. Zhang et al. ${ }^{14}$ also suggested that dyes need to be purified before ozonation treatment if detailed information on the oxidative processes and by-production formation are required.

In this context, special attention has been given to chloride ion that is additive as well as impurity for textile dyes. ${ }^{9,11,14,15,18,19,22}$ When present as additive, at relatively high concentration $\left(0.5-5 \mathrm{~g} \mathrm{~L}^{-1}\right), \mathrm{Cl}^{-}$seems to play an important role on dyes degradation processes. ${ }^{9,11,15,18}$ The possible influence of the low chloride concentration ( $<50 \mathrm{mg} \mathrm{L}^{-1}$, as an impurity) on dye ozonation has not been reported in literature. Despite the importance of chloride in this system, the mechanism of its action on dye ozonation is not completely understood.

The aim of this study is to determine the kinetics and by-products formation on the Acid Black 1 ozonation and to evaluate the influence of sodium chloride impurity on dye degradation. The reaction between $\mathrm{O}_{3}$ and $\mathrm{Cl}^{-}$was also investigated for a better understanding of the chloride suppression effect. Finally, the literature data about Acid Black 1 degradation processes as well as the chloride suppression effect on dye ozonization are discussed.

\section{Experimental}

\section{Materials}

The Acid Black 1 reagent (C.I. 20470) was obtained as a commercial dye from two suppliers Acros (purity 63.2\%) and Sigma (> 80\%). In Figure 1 the chemical structure of the dye, which has a molecular formula $\mathrm{C}_{22} \mathrm{H}_{14} \mathrm{~N}_{6} \mathrm{Na}_{2} \mathrm{O}_{9} \mathrm{~S}_{2}$ (616.48 $\left.\mathrm{g} \mathrm{mol}^{-1}\right)$ and solubility less than $0.1 \mathrm{~g} \mathrm{~L}^{-1}$ in water, is shown. The reagents were used as received and Acros dye reagent was also purified to verify the possible influence of impurities on degradation process. ${ }^{22}$ The aqueous solutions containing nominal concentrations of the 5, 10 and $20 \mathrm{mg} \mathrm{L}^{-1}$ on dye reagent were used in kinetic tests. All solutions were prepared with ultra pure water (MilliQPlus, Millipore; < $18 \mathrm{M} \Omega \mathrm{cm})$. Chloride ion work solutions were prepared using $\mathrm{NaCl}$ (Merck, 99.5\%) or $\mathrm{HCl}$ (Merck 37\%). All other reagents used were of analytical grade.

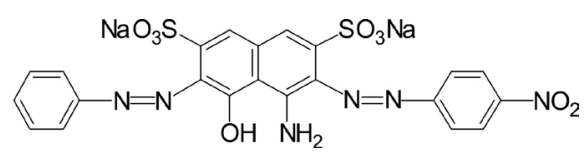

Figure 1. Chemical structure and essential properties of Acid Black 1.

Dye purification was performed following Lankin procedure, ${ }^{22}$ which consists of the several sequential washings with sodium chloride and aqueous isopropanol solutions. In this way, $5 \mathrm{~g}$ of dye was weighed into centrifuge bottle and $10 \mathrm{~mL}$ of $6 \%$ sodium chloride solution was added and shaken vigorously for $20 \mathrm{~min}$ and centrifuged (2,000 rpm) for $10 \mathrm{~min}$. The supernatant was separated and the treatment was repeated one more time with $6 \%$ sodium chloride solution and twice with aqueous isopropanol (100:20, isopropanol:water, v/v). For these washings the period of stirring was $10 \mathrm{~min}$ and then the dye was filtered using a Buchner funnel and dried in an oven at $110{ }^{\circ} \mathrm{C}$. Next the dye content on solid was estimated by its absorbance $\left(\lambda_{\max } 620 \mathrm{~nm}\right)$ on aqueous solutions using Lankin absorption coefficient $\left(E_{1 \mathrm{~cm}}^{1 \%} 921\right)$.

\section{Experimental set-up}

The experimental set-up consisted of a prototype corona discharge generator (OZ Engenharia, Brazil) which uses dried atmospheric air to generated ozone, driven by air pump with flow rate of $1.32 \pm 0.04 \mathrm{~L} \mathrm{~min}^{-1}$. Production rate was $35 \mathrm{mg} \mathrm{O}_{3} \mathrm{~h}^{-1}$, determined by iodometric and spectrophotometric methods. ${ }^{6,23}$ The on-line $\mathrm{O}_{3}$ absorbance was measured by UV-visible spectrophotometer (Micronal, B382) using a quartz flow cell (path length $10 \mathrm{~mm}$ ) at $254 \mathrm{~nm}$. Dye solutions $(0.15 \mathrm{~L})$ were ozonized in a cylindrical glass reactor (volume $0.2 \mathrm{~L}$ ) by bubbling ozone/air mixture into the solution through a sinterized glass filter (pore size 50-80 $\mu \mathrm{m}$ ). Due to the small reactor volume, $0.15 \mathrm{~L}$ fresh dye solution was used for each reaction time period studied (1 up to $25 \mathrm{~min}$ ). Excess ozone leaving the reactor was trapped by two sequential bubblers containing KI aqueous 
solution (2\%). After ozonation the samples were purged for 5 min with $\mathrm{N}_{2}$ to remove residual ozone. All experiments were conducted at room temperature $(295 \pm 1 \mathrm{~K})$.

\section{Analyses}

The optical absorption of dye solutions was determined and recorded by a UV-Vis spectrophotometer (Hewlett Packard 8453) through a $10 \mathrm{~mm}$ path length. In order to calculate the kinetics, the concentrations of the dye in solution were determined by its absorbance at maximum absorption wavelengths in the visible $(620 \mathrm{~nm})$ and UV $(321 \mathrm{~nm})$ regions following standard procedure..$^{24}$

Organic and inorganic anions and inorganic cations were determined by ion chromatography (Dionex DX500) operated in autosuppression recycle mode and equipped with a conductivity detector, detailed methods are described elsewhere. ${ }^{6}$ Ion chromatography technique (IC) allowed separation and quantification of most important low molecular carboxylic acids (formic, acetic and oxalic), inorganic anions (fluoride, chloride, nitrite, bromide, nitrate, phosphate and sulfate) and cations (sodium, potassium, calcium and magnesium). The detection limits, for all compounds, were $\leq 5 \mu \mathrm{g} \mathrm{L} \mathrm{L}^{-1}$. Chloride ion present as impurity on dye solutions was also determined by Ion Selective Electrode (ISE) using sensing (Orion, Model 9617B) and double-junction reference (Orion Model 90-02) electrodes following standard procedure. ${ }^{20}$ Conductivity (Digimed DM-41) and pH (Digimed DM-21) were also determined in some tests.

Due to the possible chloride interference on dye ozonation reaction, ${ }^{9,11,14,15}$ some experiments were performed with $\mathrm{O}_{3}$ and $\mathrm{Cl}^{-}$solutions, without the presence of Acid Black 1. For theses tests, chloride ion was supplied from either $\mathrm{NaCl}$ or $\mathrm{HCl}$ solutions $\left(2.8 \times 10^{-4} \mathrm{~mol} \mathrm{~L}^{-1}\right)$ and its concentration was monitored by IC and ISE techniques. ${ }^{6,25}$ Chloride solutions were ozonized, following the procedure described previously, and the UV-Vis spectra were obtained at different reaction times, using 10 and $100 \mathrm{~mm}$ path length cells. For comparison, the individual spectra of the sodium hypochlorite and ozone (in $0.25 \mathrm{~mol} \mathrm{~L}^{-1} \mathrm{H}_{2} \mathrm{SO}_{4}$ ) were obtained in same conditions.

\section{Results and Discussion}

\section{Dye purification}

Since the efficiency of ozonation might be affected by salt additives and/or dye reagent impurities, preliminary tests were performed to assess dye purity and the presence of possible contaminants on purified and unpurified reagents.
The purity information about dye reagents were obtained from supplier catalog and in the certificates of analysis. For Acros reagent a purity of $63.2 \%$ is mentioned while a higher content is indicated to Sigma reagent (> 80\%) both on dry basis. However, the measured dye contents for unpurified reagents indicated different values, $61.2 \pm 0.5 \%$ (moisture $12.1 \pm 0.3 \%$ ) for Acros and $86.6 \pm 0.8 \%$ (moisture $8.7 \pm 0.6 \%$ ) for Sigma on dry basis. The higher purification level was obtained for Acros reagent with dye purity increasing from 61.2 to $86.3 \%$. Same tests were performed using the purified reagent (Acros $c a .86 \%$ ).

In Figure 2 the spectra of Acid Black 1 solutions from unpurified Acros and Sigma reagents and purified Acros reagent, prepared in the same conditions $\left(20 \mathrm{mg} \mathrm{L}^{-1}\right.$, natural $\mathrm{pH})$ is shown. The three spectra presented in this figure are similar in all wavelength range studied (190-800 nm). The obtained data is also in good agreement with literature data. ${ }^{1}$ These results indicate that the presence of possible contaminants does not interfere on dye absorption.

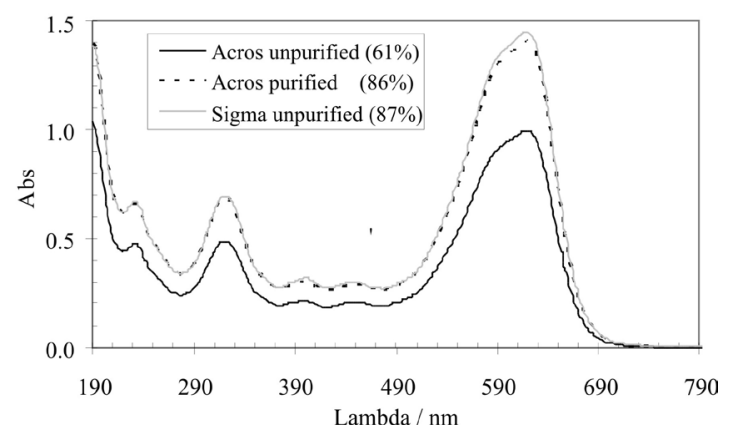

Figure 2. Spectra of the aqueous solutions (nominal concentration $20 \mathrm{mg} \mathrm{L}^{-1}$ ) prepared using two commercial grades Acid Black 1 unpurified reagents, from Acros and Sigma, and purified Acros reagent.

The IC and ISE analyses (not shown) indicated that chloride ion is the most important impurity identified on dye reagents (not ozonized). Unpurified Acros and Sigma reagents presented chloride contaminations of 6.8 and $2.0 \%(\mathrm{~m} / \mathrm{m}$ on dry basis), respectively. Phosphate ion was also identified at average level $c a .0 .5 \%$ in both unpurified dye reagents, while other anions (potential identifiable by IC) were not detected. The most abundant cations were found in the following order: $\mathrm{Na}^{+}>>\mathrm{Ca}^{2+}>>\mathrm{K}^{+}>\mathrm{Mg}^{2+}$ for unpurified dyes. These results were expected because the probable chloride counter ion is sodium..$^{22}$ On the other hand, purified Acros dye presents a significant decrease on $\mathrm{Ca}^{2+}(-98 \%)$ and $\mathrm{Na}^{+}(-42 \%)$ contents, while $\mathrm{K}^{+}$and $\mathrm{Mg}^{2+}$ levels did not change with the purification process. The inorganic impurities on the Acros reagent correspond to $c a$. $30 \%$ of the dye contamination while organic species, such as starch or other dye synthesis by-products, are responsible for $70 \%$ of the impurities. ${ }^{2}$ 


\section{Ozonation kinetics}

Preliminary tests were performed using the Acros unpurified reagent $(61 \%)$, for comparison with literature data. In Figure 3 the absorption spectra of Acid Black 1 solution $\left(1.8 \times 10^{-5} \mathrm{~mol} \mathrm{~L}^{-1}\right)$ during the ozonation process are shown. A quick decrease in absorption band at $620 \mathrm{~nm}$ was observed, resulting in a decolorized solution, suggesting a rapid destruction of the dye chromophore structure $(-\mathrm{N}=\mathrm{N}-)$ directly by ozone. Under these conditions decolorization was completed in $25 \mathrm{~min}$ reaction time. On the other hand, the absorbance at $321 \mathrm{~nm}$, wavelength generally attributed to aromatic structures, presented a less intense diminution. These results indicated that chromophore group seems to be less recalcitrant to ozone attack compared to aromatic dye moiety.

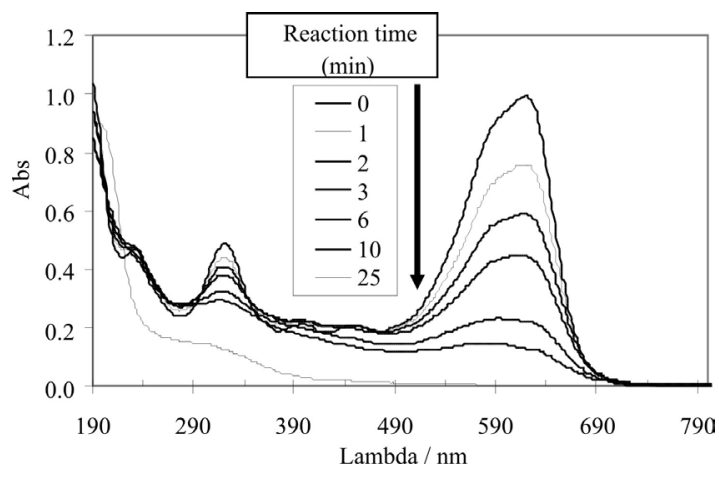

Figure 3. Absorption spectra of the Acid Black $1\left(1.8 \times 10^{-5} \mathrm{~mol} \mathrm{~L}^{-1}\right)$ solutions prepared with unpurified reagent (Acros 61\%) at different ozonation times $\left(35 \mathrm{mg} \mathrm{O}_{3} \mathrm{~h}^{-1}\right)$.

Similar results were observed for other dye concentrations studied, prepared with the same dye reagent (Acros 61\%). Complete color removal $\left(\lambda_{\max } 620 \mathrm{~nm}\right.$, A $<0.001)$ was observed after reaction times of 6 and 11 min for initial dye concentration of the $4.5 \times 10^{-6}$ and $8.9 \times 10^{-6} \mathrm{~mol} \mathrm{~L}^{-1}$, respectively.

Kinetic parameters were obtained following dye degradation at their maxima visible and UV absorption bands (620 and $321 \mathrm{~nm}$ ). The reproducibility of these calculations was evaluated by replicate tests and errors were in the range of 4.3-5.0\%. According to previous studies the ozonation in a continuous purging mode could be formulated by equation (1), considering only direct oxidation by molecular ozone. ${ }^{10,13,24}$ The indirect oxidation by hydroxyl free radicals can be neglected because the low hydroxide ion concentration in solution at $\mathrm{pH}$ used $(<5.3)$.

$\frac{d[d y e]}{t d}=-k_{0}\left[O_{3}\right][d y e]$

where $[$ dye $]$ and $\left[\mathrm{O}_{3}\right]$ are the concentrations of Acid Black 1 and ozone, and $\mathrm{k}_{0}$ is the corresponding kinetic rate constant. In addition, ozone concentration in the solution can be assumed to be constant through the continuous ozone supply thus the term $\mathrm{k}_{0}\left[\mathrm{O}_{3}\right]$ is constant, therefore the equation (1) can be simplified to,

$\frac{d[d y e]}{t d}=-k[d y e]$

where $\mathrm{k}$ is the overall pseudo-first-order rate constant. Finally, as dye concentration is proportional to absorbance (at specific $\lambda$ ), the equation (2) becomes:

$[A b s]_{t}=[A b s]_{0} e^{-t k}$

In Figure 4 the calculated logarithmic absorption ratio (at $\lambda_{\max } 620 \mathrm{~nm}$ ) for ozonation at three different initial dye concentrations is shown. These results confirmed pseudofirst order kinetics. Several authors have also reported pseudo first-order kinetics for reactions between different dyes and ozone. ${ }^{7,8,13,14,22}$ The similar result was observed at $321 \mathrm{~nm}$ (not shown) which suggests the same kinetics behavior, but at lower ozonation rate (four times slower) for aromatic degradation. A summary of the kinetics data, $\mathrm{pH}$ and conductivity measurements, obtained during Acid Black 1 ozonation, is presented in Table 1. The inverse relation between the dye concentration and the ozonation rate was observed, in accordance with literature..$^{4,5,820}$ The decrease of $\mathrm{pH}$ was expected, due to the formation of inorganic and organic acids during ozonation, confirmed by a significant conductivity increase, more pronounced for high dye concentrations.

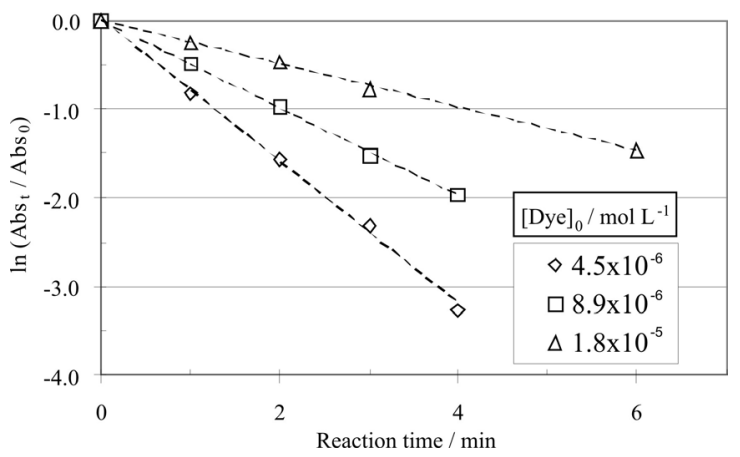

Figure 4. First-order ozonation degradation of unpurified Acid Black 1 solutions at different dye concentrations, measured by absorbance $(620 \mathrm{~nm})$ at $295 \mathrm{~K}$.

\section{By-products formation}

To achieve detailed information on the dye degradation by $\mathrm{O}_{3}$, complementary studies about ionic by-products generation were performed for ozonized solutions of the unpurified Acros dye reagent. The data presented in Table 2 
Table 1. Rate constants and reaction half-times of the ozonation of the Acid Black 1 solutions (reagent Sigma $61 \%$ ), measured at $\lambda_{\text {max. }} 620$ and $321 \mathrm{~nm}$ at ambient temperature $(295 \pm 1 \mathrm{~K})$

\begin{tabular}{|c|c|c|c|c|c|c|c|}
\hline \multirow{2}{*}{$\begin{array}{l}{\left[\text { reagent] }{ }_{0} /\right.} \\
\left(\mathrm{mg} \mathrm{L}^{-1}\right)\end{array}$} & \multirow{2}{*}{$\begin{array}{c}{[\text { dye }]_{\mathrm{o}} /} \\
\left(\mathrm{mol} \mathrm{L}^{-1}\right)\end{array}$} & \multicolumn{2}{|c|}{$620 \mathrm{~nm}$} & \multicolumn{2}{|c|}{$321 \mathrm{~nm}$} & $\mathrm{pH}$ & conductivity / $\left(\mu \mathrm{S} \mathrm{cm}^{-1}\right)$ \\
\hline & & $\mathrm{k} /\left(\mathrm{min}^{-1}\right)$ & $\mathrm{t}_{1 / 2} /(\min )$ & $\mathrm{k} /\left(\min ^{-1}\right)$ & $\mathrm{t}_{1 / 2} /(\min )$ & \multicolumn{2}{|r|}{ Initial/Final } \\
\hline 5 & $4.5 \times 10^{-6}$ & 0.80 & 0.9 & 0.19 & 3.6 & $5.22 / 4.95$ & $5.56 / 13.43$ \\
\hline 10 & $8.9 \times 10^{-6}$ & 0.50 & 1.4 & 0.12 & 5.8 & $5.27 / 4.54$ & $6.60 / 11.31$ \\
\hline 20 & $1.8 \times 10^{-5}$ & 0.26 & 2.7 & 0.10 & 6.9 & $4.96 / 4.04$ & $11.08 / 58.90$ \\
\hline
\end{tabular}

shows that sulfate and carboxylic acids (formic, oxalic and acetic) were the main oxidation by-products (chloride is also present but as a dye impurity). These species were not observed as dye contaminants (initial concentrations $<$ LD) but were actually formed during dye ozonization in all concentration conditions studied $\left(4.5 \times 10^{-6}\right.$ to $\left.1.8 \times 10^{-5} \mathrm{~mol} \mathrm{~L}^{-1}\right)$. Nitrite and phosphate (not shown) were also detected but at lower concentrations $(<1 \mu \mathrm{mol} \mathrm{L}-1)$. Formic acid is the principal organic compound formed, corresponding $40-49 \%$ of total identified short chain carboxylic acids. Oxalic acid was the second most abundant acid (34 up to $40 \%)$, with acetic acid presenting lower concentrations (0.8-4.5 $\left.\mu \mathrm{mol} \mathrm{L} \mathrm{L}^{-1}\right)$. These organic acids correspond to 8-10\% of the initial dye concentration expressed in carbon basis.

Table 2. By-products generated from ozonized solutions at different Acid Black 1 concentrations

\begin{tabular}{|c|c|c|c|c|c|c|}
\hline$[\text { dye }]_{0}\left(\mathrm{~mol} \mathrm{~L}^{-1}\right)$ & \multicolumn{2}{|c|}{$4.5 \times 10^{-6}$} & \multicolumn{2}{|c|}{$8.9 \times 10^{-6}$} & \multicolumn{2}{|c|}{$1.8 \times 10^{-5}$} \\
\hline Ozonation time (min) & \multicolumn{2}{|l|}{6} & \multicolumn{2}{|c|}{11} & \multicolumn{2}{|c|}{25} \\
\hline Organic Acids & $\mu \mathrm{mol} \mathrm{L}{ }^{-1}$ & $\%$ & $\mu \mathrm{mol} \mathrm{L}-1$ & $\%$ & $\mu \mathrm{mol} \mathrm{L}-1$ & $\%$ \\
\hline Formic & 2.4 & 49 & 4.6 & 40 & 9.6 & 40 \\
\hline Acetic & 0.8 & 17 & 2.5 & 22 & 4.5 & 20 \\
\hline Oxalic & 1.7 & 34 & 4.4 & 39 & 9.6 & 40 \\
\hline Sub-total & 4.9 & 100 & 11.5 & 100 & 23.6 & 100 \\
\hline Carbon Conversion (\%) & \multicolumn{2}{|l|}{8} & \multicolumn{2}{|c|}{9} & \multicolumn{2}{|c|}{10} \\
\hline Inorganic Anions & $\mu \mathrm{mol} \mathrm{L}-1$ & $\%$ & $\mu \mathrm{mol} \mathrm{L}-1$ & $\%$ & $\mu \mathrm{mol} \mathrm{L}^{-1}$ & $\%$ \\
\hline Nitrite & 0.7 & 40 & 0.7 & 27 & 0.9 & 8 \\
\hline Nitrate & 1.0 & 60 & 1.8 & 73 & 9.7 & 92 \\
\hline Sub-total & 1.6 & 100 & 2.4 & 100 & 10.5 & 100 \\
\hline Sulfate & 4.2 & & 9.4 & & 21.2 & \\
\hline Nitrogen Conversion (\%) & \multicolumn{2}{|l|}{6} & \multicolumn{2}{|c|}{5} & \multicolumn{2}{|c|}{10} \\
\hline Sulfur Conversion (\%) & \multicolumn{2}{|c|}{47} & \multicolumn{2}{|c|}{53} & \multicolumn{2}{|c|}{60} \\
\hline
\end{tabular}

The molecule of Acid Black 1 also contains six nitrogen atoms in the form of azo (4), amino (1) and nitro (1) groups and two sulfur atoms in the form of sulphonic groups (Figure 1). These heteroatoms react in different ways with ozone due to their specific reactivity and process conditions $\left(\mathrm{O}_{3}\right.$ dose, $\mathrm{pH}$ etc $)$, being converted in several intermediates and end-products. ${ }^{22}$ A partial transformation (5-10\%) of nitrogen atoms into nitrate and nitrite were observed. The remaining nitrogen atoms could still be in amino form or be converted into nitro-compounds, more recalcitrant to ozone attack. On the other hand, sulfonic groups seem to be easily converted to sulfate with high yields (up to 60\%). It is also observed a raise of sulfur conversion with increase of the dye concentration (from 47 to $60 \%$ ). These preliminary results and the presence of the small organic fragments (carboxylic acids) indicated that the dye structure was not completely mineralized under the prevailing oxidation conditions.

\section{Comparison with other degradation processes}

In Table 3 a summary of the literature data about Acid Black 1 degradation processes is shown. ${ }^{10,11,13,22-29}$ Only three works concerning Acid Black 1 ozonation kinetics were found and unfortunately in some studies important experimental conditions were not cited $(\mathrm{pH}$, temperature, $\mathrm{O}_{3}$ concentration etc). Shu and co-workers ${ }^{10,13}$ also obtained pseudo first-order kinetics for unpurified Acid Black 1 ozonation. A rate constant of the $0.45 \mathrm{~min}^{-1}$ was calculated for a reagent dye concentration of $20 \mathrm{mg} \mathrm{L}^{-1}$. In these conditions a $t_{1 / 2}=1.6$ min was obtained, indicating a faster kinetics compare to our system ( $\mathrm{t}_{1 / 2}$ ca. $3 \mathrm{~min}$ ). This behavior is probably due to higher ozone doses used by these authors. It is difficult to draw a comparison of these data with results obtained by Muthukumar et al. ${ }^{11}$ due to different experimental conditions used (basic medium with higher $\mathrm{O}_{3}$ and dye concentrations).

Only two degradation processes (Table 3) present faster kinetics than ozonation: $\mathrm{UV} / \mathrm{H}_{2} \mathrm{O}_{2}$ (power density $700 \mathrm{~W} \mathrm{~L}^{-1}$ ) and Fenton with $\mathrm{t}_{1 / 2}$ ca. 0.6 min..$^{26,27}$ All other processes have similar or lower kinetic rates compared to $\mathrm{O}_{3}$ treatment. However, generic conclusion must be made with caution due to the different experimental conditions used in some studies.

Another important aspect is the stated initial Acid Black 1 concentrations in Table 3, which in fact represent the dye reagent concentration. As shown in the present study, very different purities of the Acid Black 1 reagents could be found, 61 and $87 \%$ which rate constants of the 0.26 and $0.21 \mathrm{~min}^{-1}$, respectively. As consequence, significant differences on actual dye concentration are obtained 
Table 3. Kinetic data of aqueous solutions of Acid Black 1 in different degradation systems

\begin{tabular}{|c|c|c|c|c|c|c|c|c|c|}
\hline Systems & $\begin{array}{c}\text { [reagent }]^{0} / \\
\left(\mathrm{mg} \mathrm{L}^{-1}\right)\end{array}$ & & $\begin{array}{l}\text { ants } \\
\qquad\left(\mathrm{mol} \mathrm{L}^{-1}\right)\end{array}$ & $\begin{array}{c}\text { Power density / } \\
\left(\mathrm{W} \mathrm{L} \mathrm{L}^{-1}\right)\end{array}$ & $\mathrm{pH}$ & $\begin{array}{l}\mathrm{T} / \\
\left({ }^{\circ} \mathrm{C}\right) \\
\end{array}$ & $\begin{array}{c}\mathrm{k} / \\
\left(\min ^{-1}\right)\end{array}$ & $\begin{array}{l}\mathrm{t}^{1 / 2} / \\
(\min )\end{array}$ & References \\
\hline $\mathrm{O}_{3}$ & 20 & $\mathrm{O}_{3}$ & $7.2 \times 10^{-5}$ & & n.m. & n.m. & 0.44 & 2.6 & 13 \\
\hline $\mathrm{O}_{3}$ & 310 & $\mathrm{O}_{3}$ & $2 \mathrm{~g} \mathrm{~h}^{-1 \mathrm{c}}$ & & 9 & n.m. & 0.26 & 2.7 & 11 \\
\hline \multirow[t]{2}{*}{$\mathrm{O}_{3}$} & 20 & $\mathrm{O}_{3}$ & $35 \mathrm{mg} \mathrm{h}^{-1 \mathrm{c}}$ & & 5 & 20 & $0.26^{\mathrm{a}}$ & 2.9 & This work \\
\hline & 20 & $\mathrm{O}_{3}$ & $35 \mathrm{mg} \mathrm{h}^{-1 \mathrm{c}}$ & & 5 & 20 & $0.21^{\mathrm{b}}$ & 3.3 & \\
\hline $\mathrm{O}_{3}$ & 20 & $\mathrm{O}_{3}$ & n.m. & & 5.3 & n.m. & 0.45 & 1.5 & 10 \\
\hline $\mathrm{UV} / \mathrm{O}_{3}$ & 20 & $\mathrm{O}_{3}$ & n.m. & 50 & 5.3 & n.m. & 0.5 & 1.4 & \\
\hline $\mathrm{UV} / \mathrm{H}_{2} \mathrm{O}_{2}$ & 20 & $\mathrm{H}_{2} \mathrm{O}_{2}$ & $7.08 \times 10^{-3}$ & 50 & 5.3 & n.m. & 0.05 & 15 & \\
\hline $\mathrm{UV} / \mathrm{H}_{2} \mathrm{O}_{2}$ & 17 & $\mathrm{H}_{2} \mathrm{O}_{2}$ & $2.12 \times 10^{-2}$ & 700 & & & 1.10 & 0.6 & 26 \\
\hline \multirow[t]{2}{*}{ Fenton } & 46 & $\mathrm{H}_{2} \mathrm{O}_{2}$ & $5.4 \times 10^{-4}$ & & 6.3 & 30 & 1.25 & 0.6 & 27 \\
\hline & & $\mathrm{Fe}^{2+}$ & $3.4 \times 10^{-5}$ & & & & & & \\
\hline \multirow[t]{3}{*}{ Fenton } & 46 & $\mathrm{H}_{2} \mathrm{O}_{2}$ & $5.4 \times 10^{-4}$ & & 6.3 & 30 & 0.03 & 22.3 & \\
\hline & & $\mathrm{Fe}^{3+}$ & $3.4 \times 10^{-5}$ & & & & & & \\
\hline & & $\mathrm{Fe}^{2+}$ & $2.5 \times 10^{-5}$ & & & & & & \\
\hline \multirow[t]{2}{*}{ Fenton/US } & 50 & $\mathrm{H}_{2} \mathrm{O}_{2}$ & $8.0 \times 10^{-3}$ & 50 & 3 & 20 & & 1.5 & \\
\hline & & $\mathrm{Fe}^{2+}$ & $2.5 \times 10^{-5}$ & & & & & & \\
\hline \multirow[t]{2}{*}{ Photo-Fenton } & 62 & $\mathrm{H}_{2} \mathrm{O}_{2}$ & $6.4 \times 10^{-3}$ & $8 \mathrm{~W}$ & 3 & 30 & 0.194 & 3.6 & 28 \\
\hline & & Fe-Clay & $0.5 \mathrm{~g} \mathrm{~L}^{-1 \mathrm{~d}}$ & & & & & & \\
\hline TiO2/Photoc & 10 & $\mathrm{TiO}_{2}$ & & $180 \mathrm{~W}$ & 4 & n.m. & n.m. & 30 & 29 \\
\hline
\end{tabular}

${ }^{\mathrm{a}}$ Solid unpurified reagents Acros $61 \%$ or ${ }^{\mathrm{b}}$ Sigma $87 \%$; ${ }^{\mathrm{c}}$ ozone production of the O3 generators; ${ }^{\mathrm{d}} \mathrm{Fe}-$ Acetylacetonate+bentonite loading $0.5 \mathrm{~g} \mathrm{~L} \mathrm{~L}^{-1}$; n.m.: means not measured.

by using the same reagent concentration from different suppliers. For instance, a reagent concentration of $20 \mathrm{mg} \mathrm{L}^{-1}$ resulting in dye concentrations of the $1.8 \times 10^{-5} \mathrm{~mol} \mathrm{~L}^{-1}$ (unpurified Acros $61 \%$ ) and $2.4 \times 10^{-5} \mathrm{~mol} \mathrm{~L}^{-1}$ (for unpurified Sigma $87 \%$ ). If a correct dye concentration is not taken into account, kinetics data could be misinterpreA further problem is the role that those reagent impurities (for instance: 13 up to $39 \%$ in the dye reagents used in this work) could play on the dye degradation processes. Special attention has been given to the inorganic salts, normally present on dyestuff wastes from dye impurities and/or salt added during textile processing. ${ }^{15,19}$ Among these impurities, sodium chloride is a key species due to its wide use on dye synthesis and purification processes. ${ }^{19}$ Thus, the dye impurities, especially chloride ions, could be responsible for some discrepancies observed in literature data presented in Table 3.

\section{Influence of chloride ion on dye ozonation}

In Table 4 the kinetics data of Acid Black 1 ozonation in presence of the different added chloride concentrations $\left(1.4 \times 10^{-6}\right.$ up to $\left.2.8 \times 10^{-2} \mathrm{~mol} \mathrm{~L}^{-1}\right)$ is shown. The dye decay always followed pseudo-first-order kinetics no matter the $\mathrm{NaCl}$ was involved or not. However, reaction rate significantly decreased (6 up to $42 \%$ ) with chloride addition. This effect was observed for both purified and unpurified reagent (Figure 5), but in different ways. The most important influence was observed for Acros $86 \%$ $(-42 \%)$ at $5.6 \times 10^{-4} \mathrm{~mol} \mathrm{~L}^{-1}$ of the added chloride. A less intense, but significant decrease $(-35 \%)$ on rate variation, was observed for unpurified Acros dye at highest chloride concentration tested $\left(2.8 \times 10^{-2} \mathrm{~mol} \mathrm{~L}^{-1}\right)$.

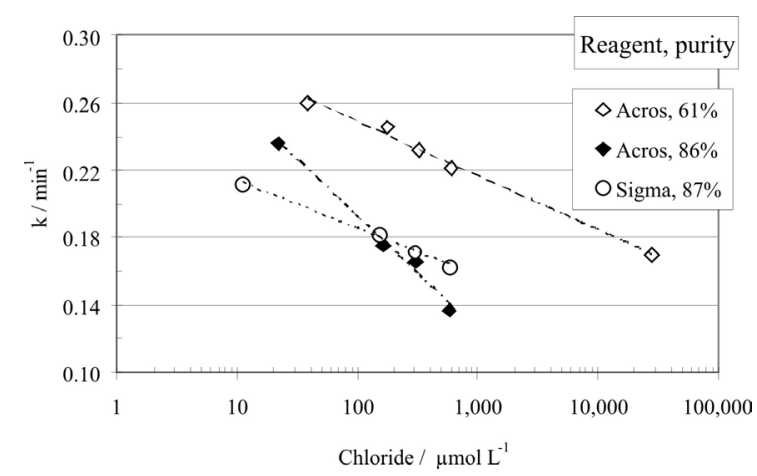

Figure 5. Influence of added chloride (as $\mathrm{NaCl}$ ) on kinetic constants of Acid Black 1 ozonization.

These results were not expected because other authors have reported a chloride suppression effect at higher $\mathrm{Cl}^{-}$concentrations..$^{911,15,16}$ Muthukumar et al. ${ }^{11,15}$ 
Table 4. Influence of the chloride added (as $\mathrm{NaCl}$ ) to the Acid Black 1 on ozonation

\begin{tabular}{|c|c|c|c|c|c|c|}
\hline $\begin{array}{l}{\left[\text { dye }_{0} /\right.} \\
\left(\mathrm{mol} \mathrm{L}^{-1}\right)\end{array}$ & $\begin{array}{l}\text { Supplier } \\
\text { purity }\end{array}$ & $\begin{array}{l}{\left[\mathrm{Cl}^{-}\right]_{\text {added }} /} \\
\left(\mu \mathrm{mol} \mathrm{L}{ }^{-1}\right)\end{array}$ & $\begin{array}{c}{\left[\mathrm{Cl}^{-}\right]_{\text {total }} /} \\
\left(\mu \mathrm{mol} \mathrm{L}{ }^{-1}\right)\end{array}$ & $\begin{array}{c}\mathrm{k} / \\
\left(\mathrm{min}^{-1}\right)\end{array}$ & $\begin{array}{l}\text { var. / } \\
(\%)\end{array}$ & $\begin{array}{c}\mathrm{t}_{1 / 2} / \\
(\mathrm{min})\end{array}$ \\
\hline \multirow{5}{*}{$1.8 \times 10^{-5}$} & \multirow{5}{*}{$\begin{array}{l}\text { Acros } 61 \% \\
\text { (not } \\
\text { purified) }\end{array}$} & 0 & $38^{\mathrm{a}}$ & 0.26 & 0 & 2.7 \\
\hline & & 141 & 179 & 0.25 & -6 & 2.8 \\
\hline & & 282 & 320 & 0.23 & -11 & 3.0 \\
\hline & & 563 & 601 & 0.22 & -15 & 3.1 \\
\hline & & 28,169 & 28,207 & 0.17 & -35 & 4.1 \\
\hline \multirow{4}{*}{$2.4 \times 10^{-5}$} & \multirow{4}{*}{$\begin{array}{l}\text { Acros } 86 \% \\
\text { (purified) }\end{array}$} & 0 & $22^{\mathrm{a}}$ & 0.24 & 0 & 2.9 \\
\hline & & 141 & 163 & 0.18 & -26 & 4.0 \\
\hline & & 282 & 304 & 0.17 & -30 & 4.2 \\
\hline & & 563 & 585 & 0.14 & -42 & 5.1 \\
\hline \multirow{4}{*}{$2.4 \times 10^{-5}$} & \multirow{4}{*}{$\begin{array}{l}\text { Sigma 87\% } \\
\text { (not } \\
\text { purified) }\end{array}$} & 0 & $11^{\mathrm{a}}$ & 0.21 & 0 & 3.3 \\
\hline & & 141 & 152 & 0.18 & -14 & 3.8 \\
\hline & & 282 & 293 & 0.17 & -19 & 4.0 \\
\hline & & 563 & 575 & 0.16 & -23 & 4.3 \\
\hline
\end{tabular}

${ }^{a}$ : chloride contaminations originally present in the reagents dye (see text).

working with concentrated chloride solutions $\left(1.4 \times 10^{-1}\right.$ to $2.6 \times 10^{-1} \mathrm{~mol} \mathrm{~L}^{-1}$ ) observed an increasing of $\mathrm{ca}$. $60 \%$ on reaction time for complete color removal. Soares et $a l .{ }^{9}$ also observed a negative effect in decolorisation of Acid Blue 113 by $\mathrm{O}_{3}$ in the presence of $\mathrm{NaCl}\left(1.4 \times 10^{-2}\right.$ to $1.4 \times 10^{-1} \mathrm{~mol} \mathrm{~L}^{-1}$ ) and verified a non linear behavior on color removal by ozone with the addition of higher chloride concentration.

The observed chloride suppression on dye ozonation rate constant is complex and indicates a possible inhibition effect at high $\mathrm{Cl}^{-}$levels. In Figure 5, logarithmic correlations between $\mathrm{k}$ and $\left[\mathrm{Cl}^{-}\right]$are obtained for three studied conditions (Acros 61 and 86\%, Sigma 87\%). These results sugested that chloride suppression is not a linear effect in our system. A more detailed discussion about this behavior is presented in the next section.

The influence of added salt on ozonation dye kinetics could be related to a simple decreasing of $\mathrm{O}_{3}$ solubility (salting effect). To test this hypothesis an empirical relation was used to account for ionic strength influence on ozone partition between gas and water phases (Henry constant). ${ }^{22}$ For higher chloride concentration $\left(2.6 \times 10^{-1} \mathrm{~mol} \mathrm{~L}^{-1}\right)$, an important reduction on $\mathrm{O}_{3}$ solubility (16\%) was calculated. This fact could in part explain the decrease on dye degradation rate observed by Muthukumar et $a l .{ }^{11}$ On the other hand, for low chloride concentration $\left(<2.8 \times 10^{-2} \mathrm{~mol} \mathrm{~L}^{-1}\right)$ an insignificant decrease on ozone solubility was estimated $(<2 \%)$. These calculations indicated that salting effects seem to remain marginal in our conditions.

Azevedo et al. ${ }^{17}$ suggested that the bromide ion, normally present as a contaminant of $\mathrm{NaCl}$, reacts with
$\mathrm{O}_{3}$ faster then $\mathrm{Cl}^{-}$generating brominated compounds. However, in the conditions tested the bromide ion was neither identified in dye solutions (LOD $<2 \mu \mathrm{g} \mathrm{L}^{-1}$ ) nor in the $\mathrm{NaCl}$ solid reagent $(<0.02 \%)$ used. Thus, the influence of chloride on Acid Black 1 degradation should take place from different mechanism, neither related to the presence of bromide nor due to a salting effect.

\section{Reaction between chloride ion and ozone}

The possible mechanism explaining the $\mathrm{Cl}^{-}$suppression effect could be a direct reaction between $\mathrm{O}_{3}$ and chloride. Yeatts and Taube ${ }^{30}$ firstly indicated that chlorine can be formed in ozone/chloride solutions in acid media as indicated in reaction A (Table 5). More recent works confirm the second order rate constant for this reaction as well as the catalytic effect of the $\mathrm{H}^{+} \cdot{ }^{31-33}$ Levanov et al. ${ }^{32,33}$ proposed the mechanism indicated by reactions B-D for this system. Siddiqui suggested that hypochlorite could react with ozone generating chloride and chlorite ions. In addition, chlorite ion could also react with $\mathrm{O}_{3}$ and produces chlorate ion by pathway shown in reactions $\mathrm{E}$ to $\mathrm{G} .{ }^{34}$

Table 5. Main reactions involved on chloride ozonation mechanism

\begin{tabular}{lcc}
\hline Number & Reaction & $\begin{array}{c}\text { Equilibrium or } \\
\text { Kinetic Constants }\end{array}$ \\
\hline $\mathrm{A}$ & $\mathrm{O}_{3}+2 \mathrm{Cl}^{-}+2 \mathrm{H}^{+} \rightarrow \mathrm{Cl}_{2}+\mathrm{H}_{2} \mathrm{O}+\mathrm{O}_{2}$ & \\
$\mathrm{~B}$ & $\mathrm{O}_{3}+\mathrm{Cl}^{-} \rightarrow \mathrm{ClO}^{-}+\mathrm{O}_{2}$ & $\mathrm{k}=1.5 \times 10^{-3} \mathrm{~L} \mathrm{~mol}^{-1} \mathrm{~s}^{-1}$ \\
$\mathrm{C}$ & $\mathrm{HOCl} \rightleftharpoons \mathrm{OCl}^{-}+\mathrm{H}^{+}$ & $\mathrm{pKa}=7.5$ \\
$\mathrm{D}$ & $\mathrm{HOCl}^{+} \mathrm{H}^{+}+\mathrm{Cl}^{-} \leftrightarrow \mathrm{Cl}_{2(\mathrm{~g})}+\mathrm{H}_{2} \mathrm{O}$ & $\mathrm{K}=2.2 \times 10^{4}$ \\
$\mathrm{E}$ & $\mathrm{ClO}^{-}+\mathrm{O}_{3} \rightarrow 2 \mathrm{O}_{2}+\mathrm{Cl}^{-}$ & $\mathrm{k}=110 \mathrm{~L} \mathrm{~mol}^{-1} \mathrm{~s}^{-1}$ \\
$\mathrm{~F}$ & $\mathrm{ClO}^{-}+\mathrm{O}_{3} \rightarrow \mathrm{O}_{2}+\mathrm{ClO}_{2}^{-}$ & $\mathrm{k}=30 \mathrm{~L} \mathrm{~mol}^{-1} \mathrm{~s}^{-1}$ \\
$\mathrm{G}$ & $\mathrm{ClO}_{2}^{-}+\mathrm{O}_{3} \rightarrow \mathrm{O}_{2}+\mathrm{ClO}_{3}^{-}$ & $\mathrm{k}=4 \times 10^{6} \mathrm{~L} \mathrm{~mol}^{-1} \mathrm{~s}^{-1}$ \\
\hline
\end{tabular}

Levanov et al. ${ }^{32,33}$ suggested that $\mathrm{Cl}_{2}$ formation and its release into a gas phase result from a rapidly established equilibrium. Unfortunately it is very difficult to identify chlorine gas in the presence of the ozone, especially at low reactants concentration used. On the other hand, a decrease in the chloride level in ozonized solutions, with a concomitant hypochlorite generation, could be an alternative form to confirm the proposed mechanism.

Our experimental results indicated a significant decrease on $\mathrm{Cl}^{-}$concentration $(-20 \%)$ for ozonized hydrochloric acid solutions $\left(2.8 \times 10^{-4} \mathrm{~mol} \mathrm{~L}^{-1}\right.$ in $\mathrm{Cl}^{-}$, $\mathrm{pH} 1$ ) without the presence of dye. As expected, this effect was not observed in sodium chloride solution $\left(2.8 \times 10^{-}\right.$ ${ }^{4}$ mol L-1 in $\left.\mathrm{Cl}^{-}, \mathrm{pH} 6\right)$ probably due to low $\left[\mathrm{H}^{+}\right]$. In order to verify the possible formation of the hypochlorous acid $(\mathrm{HOCl}), \mathrm{UV}$ spectra of these solutions were recorded. 
For dilute $\mathrm{HCl}$ concentration $\left(\leq 0.1 \mathrm{~mol} \mathrm{~L}^{-1}\right)$ only the peaks of ozone $(254 \mathrm{~nm})$ and chloride $(c a .200 \mathrm{~nm})$ were detected. However, on increasing $\mathrm{HCl}$ concentration up to $0.5 \mathrm{~mol} \mathrm{~L}^{-1}$, a new peak around $230 \mathrm{~nm}$ appears, while ozone peak $(254 \mathrm{~nm}$ ) is no longer observed (Figure 6). This new peak is close to the $\mathrm{HOCl} \lambda_{\text {max }}(230 \mathrm{~nm})$ one, as could be observed in the spectrum obtained from a $\mathrm{NaOCl}$ acidic solution (in $0.25 \mathrm{~mol} \mathrm{~L}^{-1} \mathrm{H}_{2} \mathrm{SO}_{4}$ ) also shown in Figure 6.

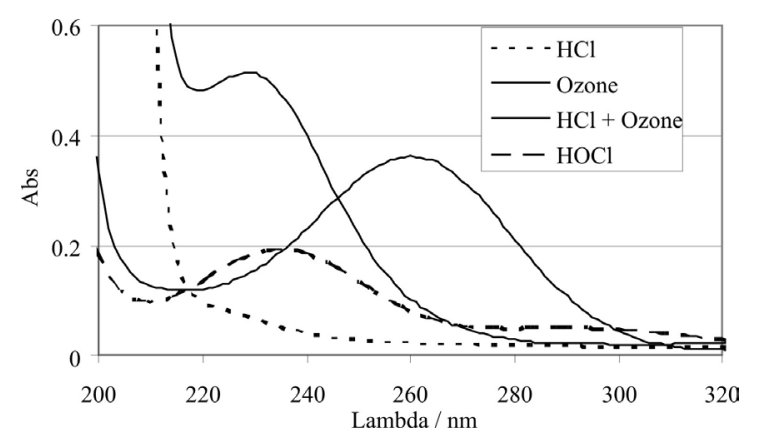

Figure 6. Spectra UV-Vis of the aqueous solutions: $0.5 \mathrm{~mol} \mathrm{~L}^{-1} \mathrm{HCl}$ (ozonized and not ozonized) and $\mathrm{HOCl}\left(2 \times 10^{-3} \mathrm{~mol} \mathrm{~L}^{-1}\right.$ in $0.25 \mathrm{~mol} \mathrm{~L}^{-1}$ $\left.\mathrm{H}_{2} \mathrm{SO}_{4}\right)$ and ozone $\left(1.2 \times 10^{-4} \mathrm{~mol} \mathrm{~L}^{-1}\right.$ in $\left.0.25 \mathrm{~mol} \mathrm{~L}^{-1} \mathrm{H}_{2} \mathrm{SO}_{4}\right)$.

Similar behavior was observed by Vinals et al..$^{35}$ studying the influence of chloride ion on the ozone assisted leaching of gold and palladium from metallic scraps. These authors verified the presence of a peak around $230 \mathrm{~nm}$ and attributed to the presence of $\mathrm{HOCl}$, for chloride concentration up to $0.5 \mathrm{~mol} \mathrm{~L}^{-1}$.

It is possible that hypochlorous acid formation could also take place in slight acid solutions $(\mathrm{pH} 4)$ and at low $\mathrm{O}_{3}$ and chloride concentrations, such as the ones used in this study. If true, the direct reaction between $\mathrm{O}_{3}$ and chloride could compete with dye ozonation and explain, at least in part, the observed $\mathrm{Cl}^{-}$suppression effect on Acid Black 1 degradation. However, the global mechanism is probably more complex than that considered in this work. The presence of dye could directly influence the chloride reaction with ozone and their by-products also could interact among them, generating different products. Thus, for a best elucidation of the involved mechanism and to a precise estimation of chloride suppression effect further tests must be performed using more sensitive analytical techniques, free of interference.

\section{Conclusions}

Experimental results show that ozonation of Acid Black 1 solutions is very efficient in the destruction of the dye chromophore structures. Ozonation treatment leads to a complete decolorization of the dye solution $\left(1.8 \times 10^{-5} \mathrm{~mol} \mathrm{~L}^{-1}\right)$ in few minutes $(<25 \mathrm{~min})$. In addition, the aromatic structures are also attacked but at slower rates. Pseudo first-order rate kinetics were obtained, with an inverse relation between initial dye concentration and rate constant.

The ozonized unpurifed dye solutions showed the presence of short chains carboxylic acids (formic, oxalic and acetic) and inorganic anions (sulfate, nitrate and nitrite) as degradation by-products. The calculated conversions on molar ratios suggest that dye structure was not completely mineralized under used conditions.

The dye purity is a very important parameter not just to state the real dye concentration but also to indicate the presence of impurities which could be reactive towards $\mathrm{O}_{3}$. The main identified contaminant (chloride ion) affects significantly the dye ozonation kinetics. Interference studies indicated that rate constants decrease up to $42 \%$ in the presence of $5.6 \times 10^{-4} \mathrm{~mol} \mathrm{~L}^{-1}$ added chloride. However, the presence of other impurities could also interfere in the dye degradation. The mechanism of the chloride suppression effect seems to involve a direct reaction between $\mathrm{O}_{3}$ and $\mathrm{Cl}^{-}$generating $\mathrm{HOCl}$, among other by-products.

\section{Acknowledgments}

The authors thank FAPERGS and CNPq for financial support.

\section{References}

1. Green, F. J.; The Sigma-Aldrich Handbook of Stains, Dyes and Indicators, Aldrich Chemical Co.: Milwaukee, Wisconsin, 1991.

2. Borrós, S.; Barbera, G.; Biada, J.; Agulló, N.; Dyes Pigm. 1999, $43,189$.

3. Carneiro, P. A.; Boralle, N.; Stradiotto, N. R.; Furlan, M.; Zanoni, M. V. B.; J. Braz. Chem. Soc. 2004, 15, 587.

4. Catanho, M.; Malpass, G. R. P.; Motheo, A. J.; Quim. Nova. 2006, 29, 983.

5. Almeida Filho, C.; Zarbin, J. G.; J. Braz. Chem. Soc. 2006, 17, 1151.

6. Martins, A. O.; Canalli, V. M.; Azevedo, C. M. N.; Pires, M.; Dyes Pigm. 2006, 68, 227.

7. Alaton, I. A.; Balcioglu, I. A.; Bahnemann, D. W.; Water Res. 2002, 36, 1143.

8. Sarayu, K.; Swaminathan, K.; Sandhya, S.; Dyes Pigm. 2007, 75,362 .

9. Soares, O. S. G. P.; Órfão, J. J. M.; Portela, D.; Vieira, A.; Pereira, M. F. R.; J. Harzard. Mater. B. 2006, 137, 1664.

10. Shu H. Y; Chang M. C.; Dyes Pigm. 2005, 65, 25.

11. Muthukumar, M.; Sargunamani, D.; Selvakumar, N.; Nedumaran, D.; Indian J. Chem. Technol. 2004, 11, 612. 
12. Tosik R.; Wiktorowski, S.; Ozone Sci. Eng. 2001, 23, 295.

13. Shu H. Y.; Huang C. R.; Chemosphere 1995, 31, 3813.

14. Zhang, F. F.; Yediler, A.; Liang, X. M.; Kettrup, A.; Dyes Pigm. 2004, 60, 1.

15. Muthukumar, M.; Selvakumar, N.; Dyes Pigm. 2004, 62, 221.

16. Chu, W.; Lau, T. K.; J. Hazard. Mater. 2007, 144, 249.

17. Azevedo, E. B.; Neto, F. R. D.; Dezotti, M.; J. Hazard. Mater. 2006, 128, 182.

18. Dong, Y.; Chen, J.; Li, C.; Zhu H.; Dyes Pigm. 2007, 73, 261.

19. Gahr, F.; Hermanutz F.; Oppermann W.; Water Sci. Technol. 1994, 30, 255.

20. Gunten U.; Water Res. 2003, 37, 1469.

21. Lyon, H. O.; Biotechnic Histochem. 2002, 77, 57.

22. Lankin, A. L.; Chem. Ind. 1970, 38, 1227.

23. Standard Methods for the Examination of Water and Wastewater - APHA, 20 ${ }^{\text {th }}$ ed.; American Public Health Association/ American Water Works Association/Water Environment Federation, Washington DC, 1998.

24. Langlais, B.; Reckhow, D. A.; Brink, D. R.; Ozone in Water Treatment Applications and Engineering, AWWARF and Lewis Publishers, Inc.: Denver, 1991.

25. Evans, A.; Potentiometry and Ion Selective Electrodes, J. Wiley:, London, 1991.
26. Shu, H. Y.; Chang, M. C.; Fan, H. J.; J. Hazard. Mater. 2004, $113,201$.

27. Wang, S.; Dyes Pigm. 2008, 76, 714.

28. Yip, A. C. K.; Lam, F. L. Y.; Hu, X.; Chem. Eng. Sci. 2007, 62, 5150.

29. Grzechulska, J.; Morawski, A. W.; Appl. Catal. B - Environ. 2002, 36, 45.

30. Yeatts, L. R. B.; Taube, H.; J. Am. Chem. Soc. 1949, 71, 4100.

31. Hoigne, J.; Bader, H.; Haag, W. R.; Staehelin, J.; Water Res. 1985, 19, 993.

32. Levanov, A. V.; Kuskov, I. V.; Zosimov, A. V.; Antipenko, E. E.; Lunin, V. V.; Kin. Catal. 2003, 44, 740.

33. Levanov, A. V.; Kuskov, I. V.; Koiaidarova, K. B.; Zosimov, A. V.; Antipenko, E. E.; Lunin, V. V.; Kin. Catal. 2005, 46, 147.

34. Siddiqui, M.; Water Res. 1996, 30, 2160.

35. Vinals, J.; Juan, E.; Ruiz ,M.; Ferrando, E.; Cruells, M.; Roca, A.; Casadao, J.; Hydrometal. 2006, 81, 142.

Received: July 17, 2009

Web Release Date: December 3, 2009 